\title{
Penguatan produk Usaha Mikro Kecil dan Menengah (UMKM) yang berbasis Hak Kekayaan Intelektual (HKI) dalam rangka perdagangan bebas ASEAN
}

\author{
Adi Tiaraputri*, Zulfikar Jayakusuma, Evi Deliana HZ, Maria Maya Lestari, Widia Edorita, \& \\ Ledy Diana
}

Universitas Riau

*aditiaraputri@gmail.com

\begin{abstract}
Abstrak. Bagi pelaku usaha mikro kecil dan menengah (UMKM) untuk memulai usahanya perlu memikirkan perlindungan Hak Kekayaan Intelektual (selanjutnya disebut HKI). Jikalau, para pelaku usaha mikro kecil dan menengah (UMKM) tidak memikirkan perlindungan HKI, maka karya para pelaku usaha dapat mudah terjadi pelanggaran HKI. Oleh karena itu, pada masa awal memulai bisnisnya, mereka seharusnya sudah memberikan perlindungan HKI-nya, sebab HKI sejatinya dapat menjadi aset berharga yang bisa menyelamatkan perusahaan di masamasa sulit. HKI sejatinya adalah hak yang muncul dari hasil oleh pikir atau kreasi manusia yang pada akhirnya menghasilkan suatu produk atau proses yang berguna bagi manusia. Dalam dunia bisnis, HKI bisa menjadi elemen penting karena dapat memberikan keunggulan berkompetisi ketika bermain di pasar yang dibidik bagi pemiliknya. Bahkan, tak menutup kemungkinan pula HKI ini dapat menjadi pemicu untuk memunculkan berbagai inovasi baru bagi pelaku usaha mikro kecil dan menengah (UMKM) yang pada akhirnya dapat menguntungkan publik juga para pelaku usaha itu sendiri, misalnya dalam menghadapi perdagangan bebas ASEAN. Tujuan dilaksanakan kegiatan pengabdian masyarakat ini adalah sosialisasi aspek HKI bagi para pelaku UMKM di Kabupaten Kampar. Metode penerapan yang dipilih adalah sosialisasi atau desiminasi ilmu pengetahuan, dalam hal ini adalah penyebaran informasi tentang HKI dan tata cara pendaftaran HKI. Dari kegiatan pengabdian ini, pelaku usaha UMKM di Kabupaten Kampar menyadari penting aspek HKI untuk kemajuan usaha.
\end{abstract}

Kata kunci: usaha mikro kecil dan menengah; hak kekayaan intelektual; perdagangan; pelaku usaha

To cite this article: Tiaraputri, A., Z. Jayakusuma, E. Deliana HZ, M. M. Lestari, W. Edorita, \& L. Diana. 2019. Penguatan produk Usaha Mikro Kecil dan Menengah (UMKM) yang berbasis Hak Kekayaan Intelektual (HKI) dalam rangka perdagangan bebas ASEAN. Unri Conference Series: Community Engagement 1: $466-469$ https://doi.org/10.31258/unricsce.1.466-469

(C) 2019 Authors

Peer-review under responsibility of the organizing committee of Seminar Nasional Pemberdayaan Masyarakat 2019 


\section{PENDAHULUAN}

Di Indonesia, usaha mikro kecil dan menengah (selanjutnya di dalam tulisan ini menggunakan istilah UMKM) memiliki kontribusi yang cukup besar dalam perluasan kesempatan kerja dan penyerapan tenaga kerja. UMKM bisa juga dikatakan sebagai motor penggerak perekonomian di Indonesia. Pada tahun 2016 jumlah pelaku UMKM di Indonesia dilaporkan mencapai 49 juta dan diprediksi menyerap lebih dari 107 juta tenaga kerja dan kontribusi sektor UMKM terhadap produk domestik bruto (PDB) pun semakin meningkat dalam lima tahun terakhir di mana Kementerian Koperasi dan Usaha Kecil Menengah mencatat lonjakan dari 57,84 persen menjadi 60,34 persen (Andrian Gunandi, 2017).

Bagi pelaku usaha untuk memulai usahanya perlu memikirkan perlindungan Hak Kekayaan Intelektual (selanjutnya disebut HKI). Jikalau, para pelaku usaha tidak memikirkan perlindungan HKI, maka karya para pelaku usaha dapat mudah diklaim pihak lain. Oleh karena itu, pada masa awal memulai bisnisnya, mereka seharusnya sudah memberikan perlindungan HKI-nya, sebab HKI sejatinya dapat menjadi aset berharga yang bisa menyelamatkan perusahaan di masa-masa sulit.

HKI sejatinya adalah hak yang muncul dari hasil oleh pikir atau kreasi manusia yang pada akhirnya menghasilkan suatu produk atau proses yang berguna bagi manusia. Dalam dunia bisnis, HKI bisa menjadi elemen penting karena dapat memberikan keunggulan berkompetisi ketika bermain di pasar yang dibidik bagi pemiliknya. Bahkan, tak menutup kemungkinan pula HKI ini dapat menjadi pemicu untuk memunculkan berbagai inovasi baru bagi perusahaan yang pada akhirnya dapat menguntungkan publik juga para pelaku usaha itu sendiri (Adjie Priambada: 2018).

Ketika diterapkan, penerapan HKI bagi para pelaku usaha yang ada di daerah bisa mengalami beberapa kesulitan. Ada beberapa permasalahan yang kini timbul dalam konteks sistem perlindungan HKI di daerah. Pertama, permasalahan perlindungan kekayaan intelektual berbiaya tinggi dan mahal. Sebagaimana diketahui untuk memberikan perlindungan kekayaan intelektual, seseorang atau badan hukum yang memiliki kekayaan intelektual harus melakukan pengurusan pendaftaran kekayaan intelektual. Dalam proses mengurus perlindungan kekayaan intelektual di daerah identik dengan biaya tinggi dan mahal. Anggapan biaya tinggi dan mahal dikarenakan dalam proses pengurusan perlindungan kekayaan intelektual di daerah kadangkala ada biaya-biaya di luar mekanisme pendaftaran kekayaan intelektual. Di samping itu, ketiadaanaturan tentang tarif konsultan HKI, sehingga kecenderungan konsultan HKI menerapkan biaya menjadi tidak terukur (Budi Agus Riswandi, 2009). Kedua, prosedur yang masih berbelit-belit. Sudah menjadi pengetahuan umum bahwa untuk mengurus pendaftaran kekayan intelektual di daerah membutuhkan proses yang panjang dan berbelit-belit. Adanya kesan proses yang panjang dan berbelit-belit ini diakibatkan karena dua hal, yakni; (i) Pihak yang memohon sendiri tidak memiliki pengetahuan kaitannya dengan prosedur pengurusan pendaftaran kekayaan intelektual; dan (ii) Sistem perlindungan dan pengelolaan kekayaan intelektual di daerah sendiri masih membingungkan bagi pemohon. Kebingungan tersebut disebabkan aspek kelembagaan yang menangani persoalan pendaftaran pengurusan kekayaan intelektual di daerah sendiri masih ditangani banyak lembaga (Budi Agus Riswandi, 2009). Ketiga, belum adanya lembaga yang secara khusus melakukan advokasi atas pelanggaran kekayaan intelektual yang dimiliki oleh masyarakat di daerah. Hingga saat ini, ketentuan hukum dalam bidang HKI sebagai besar menyerahkan persoalan advokasi atas pelanggaran kekayaan intelektual yang dimiliki oleh masyarakat di daerah diurusi oleh pemegang hak itu sendiri. Dengan kenyataan ini, maka tidak sedikit masyarakat di daerah yang memegang hak atas kekayaan intelektual tidak dapat melakukan advokasi. Ketidakmampuan melakukan advokasi ini salah satu alasannya dikarenakan apabila tindakan advokasi itu dilakukan sendiri oleh mereka, maka dianggap sesuatu yang tidak efektif dan efisien. Alhasil, pelanggaran atas hak kekayaan intelektual yang mereka miliki kecenderungannya dibiarkan saja berlalu (Budi Agus Riswandi, 2009).

Untuk mencoba mengurangi permasalahan HKI di daerah, tim pngabdian mencoba untuk melakukan penyuluhan hukum terkait HKI di daerah. Kegiatan pengabdian ini juga bermaksud untuk membantu UMKM meningkatkan produk mereka agar mampu bersaing pada perdagangan di kawasan ASEAN. Dan kesempatan ini, tim pengbadian mencoba mengambil tempat penyuluhan di Riau, tepatnya di Kabupaten Kampar. Adapun menurut data Dinas Koperasi UMKM Provinsi Riau, usaha mikro kecil dan menengah yang ada di daerah Riau pada 2014 sebanyak 534.504 unit dan adapun produk unggulannya adalah produk pangan olahan (Arif Gunawan, 2015).

Berdasarkan uraian diatas, maka yang menjadi identifikasi masalah dalam kegiatan pengabdian ini adalah sejauh mana para pelaku UMKM di Provinsi Riau terutama di Kabupaten Kampar mengetahui perlindungan Hak Kekayaan Intelektual. Adapun perumusan masalah dari kegiatan pengabdian ini adalah: 
1. Apa saja ruang lingkup perlindungan HKI bagi para pelaku UMKM?

2. Bagaimana tata cara pendaftran HKI?

Merujuk kepada latar belakang yang diuraikan, maka beberapa hal yang menjadi tujuan kegiatan yang ingin dicapai adalah tersosialisaikannya aspek HKI bagi para pelaku UMKM di daerah Kampar. Sedangkan manfaat kegiatan pengabdian ini adalah sebagai berikut:

1. Menjadi sarana menyebarkan informasi yang berkaitan pendaftaran HKI;

2. Bentuk Tri Dharma Perguruan Tinggi, dalam hal pengabdian kepada masyarakat;

3. Merupakan sarana menyebarkan ilmu pengetahuan, khususnya Hukum Hak Kekayaan Intelektual;

4. Masyarakat sasaran dapat mengimplementasikan secara langsung ilmu pengetahuan yang telah diperoleh dari kegiatan pengabdian ini.

Hak Kekayaan Intelektual, disingkat "HKI" atau adalah padanan kata yang biasa digunakan untuk Intellectual Property Rights (IPR), yakni hak yang timbul bagi hasil olah pikir yang menghasikan suatu produk atau proses yang berguna untuk manusia pada intinya HKI adalah hak untuk menikmati secara ekonomis hasil dari suatu kreativitas intelektual. Objek yang diatur dalam HKI adalah karya-karya yang timbul atau lahir karena kemampuan intelektual manusia. Secara garis besar HKI dibagi dalam 2 (dua) bagian, yaitu:

1. Hak Cipta (copyright);

2. Hak kekayaan industri (industrial property rights), yang mencakup:

a. Paten (patent);

b. Desain industri (industrial design);

c. Merek (trademark);

d. Penanggulangan praktek persaingan curang (repression of unfair competition);

e. Desain tata letak sirkuit terpadu (layout design of integrated circuit);

f. Rahasia dagang (trade secret).

Pada dasarnya, relevansi HKI bagi UMKM dapat digunakan sebagai sarana untuk melakukan inovasi terhadap suatu produk. Hal ini dikarenakan syarat untuk mendapatkan perlindungan atas kekayaan intelektual yang diformat dalam bentuk pemberian HKI salah satunya adalah harus adanya unsur kebaruan. Dengan adanya syarat seperti ini bagi UMKM akan terdorong untuk mampu menghasilkan produk yang lebih inovatif dan kreatif. Semisal; desain industri sebagai suatu bentuk rancangan produk yang dapat berupa bentuk, konfigurasi dan komposisi dapat dilindungi apabila mempunyai unsur kebaruan, estetika dan terdaftar. Dengan kondisi demikian, desain industri tersebut jelas akan mampu menghasilkan inovasi terhadap produk, mengingat rancangan desain produknya diharuskan selalu mempunyai unsur kebaruan jika ingin dilindungi. Inovasi ini tentunya tidak sekedar dari kebaruan suatu rancangannya, tetapi juga nuansa estetikanya. Relevansi lain dari HKI bagi penguatan UMKM adalah HKI memiliki arti yang sangat strategis untuk UMKM. Dengan adanya HKI, UMKM dapat melakukan keberlanjutannya. Bahkan dengan HKI, UMKM juga dapat melakukan ekspansi pasar (Nurhasanah Harahap, 2014).

\section{METODE PENERAPAN}

Metode penerapan yang dipilih adalah sosialisasi atau desiminasi ilmu pengetahuan, dalam hal ini adalah penyebaran informasi tentang HKI dan tata cara pendaftaran HKI. Penyuluhan hukum ini nantinya akan menggunakan alat bantu berupa slide atau bahan presentasi yang kemudian akan dipaparkan kepada masyarakat sasaran. Selanjutnya akan dilakukan tanya jawab mengenai sejauh mana informasi yang diberikan telah dipahami.

Tahap persiapan pada kegiatan ini merupakan tahap yang diperlukan untuk mengumpulkan informasi yang berkaitan dengan kelompok sasaran. Tahap persiapan ini terdiri dari:

1. Mengumpulkan data calon peserta terutama yang berkaitan masyarakat yang yang mempunyai Usaha Mikro Kecil dan Menengah

2. Diskusi dengan anggota pelaksana dan penentuan beban kerja anggota tim.

3. Mempersiapkan media dan perangkat yang diperlukan dalam sosialisasi.

Tahapan selanjutnya yaitu tahapan pelaksanaan berupa ceramah/presentasi mengenai materi tentang relevansi HKI dan UMKM, prosedur pendaftaran HKI, dan hal lainnya yang dirasa perlu. Dalam tahapan ini dibuka kesempatan juga kepada peserta untuk bertanya kepada pemateri terkait dengan materi disampaikan. 


\section{HASIL DAN KETERCAPAIAN SASARAN}

Penyuluhan hukum tentang penguatan produk usaha mikro kecil dan menengah (UMKM) yang berbasis Hak Kekayaan Intelektual (HKI) dalam rangaka perdagangan bebas ASEAN telah dilaksanakan di Bangkinang, Kabupaten Kampar. Penyuluhan hukum ini dilaksanakan pada hari Jumat tanggal 10 Agustus 2018, dimulai pada pukul 13.30 WIB. Acara ini di ikuti oleh 46 (Empat Puluh Enam) orang peserta. Masyarakat diberikan penyuluhan adalah warga masyarakat yang mempunyai produk dari UMKM. Peserta penyuluhan sangat antusias untuk mengikuti acara ini karena mereka menyadari bahwa bekal pengetahuan yang mereka dapatkan nantinya akan bermanfaat untuk meningkatkan pengetahuan mereka di Bidang Hukum, terutama yang terkait dengan HKI.

Dalam penyuluhan ini, tim melihat masih awamnya HKI pada pelaku usaha UMKM. HKI merupakan sesuatu yang tergolong baru bagi pelaku usaha. Pelaku usaha juga sedikit terbebani dengan biaya terkait dengan HKI seperti Merek. Setelah melakukan penyuluhan, tim ada melihat ketertarikan peserta untuk mendaftarkan merek dagang mereka.

\section{KESIMPULAN}

Dari adanya penyuluhan ini diketahui bahwa masih banyaknya masyarakat yang belum mengetahui HKI bagi produk UMKM, pelaku usaha juga kurang paham akan pentingnya HKI serta relevansi HKI dan UMKM. Perlu dilakukannya penyuluhan secara berlanjut mengenai pendaftaran HKI ke pelaku usaha UMKM bekerjsama dengan instansi terkait agar mereka dapat bersaing dalam masa perdagangan bebas yang berlaku saat ini.

\section{UCAPAN TERIMA KASIH}

Tim mengucapkan terima kasih kepada bapak/ ibu pelaku usaha UMKM di Kabupaten Kampar yang bersedia ikut dalam kegiatan pengabdian masyarakat yang ditaja bagian Hukum Internasional.

\section{DAFTAR PUSTAKA}

Gunandi, A. 2017. Potensi Bangkit UMKM dan Industri Kreatif melalui Peer to Peer Landing. https://ekonomi.kompas.com/read/2017/04/04/123000526/potensi-bangkitnya-umkm-dan-industri-kreatifmelalui-peer-to-peer-lending-. Diakses pada 2 Mei 2018.

Gunawan, A. 2015. Riau Unggulkan UMKM Olahan Pangan. http://industri.bisnis.com/read/20150512/87/432643/riauunggulkan-umkm-olahan-pangan. Diakses pada 2 Mei 2018.

Harahap, N. 2014. Relevansi Hak Kekayaan Inteleektual Untuk Usaha Kecil Menengah (UKM). https://nurhasanahharahap25212492.wordpress.com/2014/04/11/relevansi-hak-kekayaan-intelektual-untukusaha-kecil-menengah-ukm-/. Diakses pada 2 Mei 2018.

Priambada, A. 2018. Arti Hak Kekayaan Intelektual bagi Starup dan Usaha Kecil Menengah. https://dailysocial.id/post/hki-startup-ukm. Diakses pada 2 Mei 2018.

Riswandi, B. A. 2009. Gagasan Perlindungan Kekayaan Intelektual yang Pro Industri Kreatif. http://www.hukumonline.com/berita/baca/hol21024/gagasan-perlindungan-kekayaan-intelektual-yang-proindustri-kreatif. Diakses pada 2 Mei 2018. 